\title{
CONFEDERATE AGENTS IN CANADA DURING THE AMERICAN CIVIL WAR
}

THE secret military and political organization which the Con-

federacy of the Southern States built up in Canada during the Civil War centred mainly about the personality of the Hon.

- Jacob Thompson. This typical soldier politician had been Secretary of the Interior in. President Buchanan's cabinet at Washington; and from the day when, as a member of the cabinet, he had opposed the sending of troops to Charleston (although civil war was even then imminent), to the day when the Washington government offered a reward of $\$ 25,000$ for his capture, the North had no more implacable enemy. His arrival in Toronto in 1864, when the American Civil War was raging at its hottest, marked the beginning of a series of conspiracies on which Canadian historians have hitherto laid little emphasis.

"Rebel sympathizers" in Canada had begun to worry the Union authorities as early as the end of 1863 . In December, 1863, C. S. Ogden, the American consul at Quebec, for instance, wrote to his government begging them to take some steps for the protection of the border states in order to "prevent the consummation of contemplated deeds of reckless wickedness." But just what the deeds contemplated were was not apparent; nor does there appear to have been as yet any definite organization of the Confederates in Canada.

The future leader of Confederate activities was, in fact, at this time still busy in the South. He had left the Federal cabinet to reappear as a "volunteer A.D.C." to General Beauregard at the battle of Shiloh, in April, 1862. The exact duties of a volunteer A.D.C. appear probably in no military manual, but it is easy to picture the eminent politician bursting with the desire for military laurels and influential enough to have his requests granted, offering himself and his horse for the duty of carrying orders amid the smoke of battle. General Beauregard mentions him in his report of the battle, and the volunteer A.D.C. himself made a report regarding his own and his general's movements: 
"While I was engaged," he writes, "in rallying our disorganized troops to the left and rear of the Church, you seized the banners of two different regiments and led them forward in face of the fire of the enemy; but from the feebleness of the response I became convinced that our troops were too much exhausted to make a vigorous resistance. I rode up to you and advised that you should expose yourself no further, but should dispose your troops so as to retire from Shiloh Church in good order."

Soon after we find him going quite openly to Helena, Arkansas, and the general in command of the Federal troops on the Missouri writes plaintively to his subordinate: "I understand noted rebel ex-officers, including the arch-traitor Jacob Thompson have been at Helena without being hung. Any such monstrous breaches of military law and reason will be severely noticed." Major Thompson, however, continued to escape the Federal gallows and next made his appearance as Inspector-General under General Pemberton at Vicksburg. This appointment turned out to be not quite so pleasant as it might have been, for Vicksburg was promptly invested; but as soon as arrangements had been made for its surrender, Colonel (he had gone up a step) Thompson departed on an errand to General Johnston, while the rest of the garrison were waiting to go through the formalities of parole.

It was at this stage that his energies were transferred to Canada. The Confederate sympathizers in Canada, whose schemes had been disturbing Mr. Ogden, had been thought worthy of notice by the Southern chiefs; and Jefferson Davis sent for Thompson in April, 1864, and finally dispatched him for duty in Canada under the following commission:

Hon. Jacob Thompson.

SIR,

Confiding special trust in your zeal, discretion and patriotism, I hereby direct you to proceed at once to Canada, there to carry out such instructions as you have received from me verbally, in such manner as shall seem most likely to conduce to the furtherance of the interests of the Confederate States of America which have been intrusted to you.

Very respectfully and truly yours,

(Signed) JefFerson Davis.

With Thompson, and under a similar authority, went the Hon. C. C. Clay, another Southern politician. Just how two

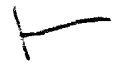
men who were so well known and would, we might have thought, 
have been easy to identify succeeded in passing all the Northern lines, has never been explained, but by July, 1864, they had established themselves in Toronto, and had commenced operations, Thompson going under the name of Captain Carson, and Clay calling himself at various times Hope, Tracey, and Lacey.

It was not long before their presence became known to the Union authorities, who naturally apprehended trouble. General Hitchcock, who was in command at Sandusky, wrote off to the Secretary reporting that ex-secretary Thompson was "employed in Canada setting on foot expeditions of the most dangerous character," and recommending that gunboats should be placed on the lakes.

He was quite justified in his apprehensions. Almost as soon as Thompson arrived in Canada, he advanced $\$ 2,000$ to a $\mathrm{Mr}$. Minor Major, who seems to have had no credentials, but was anxious to burn steamboats on the Mississippi. As some steamboats were soon after burned at St. Louis, Thompson appears to have been satisfied that he had had value for his money, and proceeded to finance a Mr. Churchill of Cincinnati, who wished to form an Incendiary Corps in that city. Cincinnati, however, got off better than the St. Louis steamboats.

There was at this time on Lake Erie a solitary American gunboat, the U.S.S. Michigan, and it was not long before the eyes of the ex-secretary and ex-aide-de-camp were turned in her direction. A useful assistant was, as usual, ready to his hand in Captain Charles H. Cole, who, he says, "represented to me that he had been appointed a lieutenant in our navy." Captain Cole professed that he had already paved the way by getting on good terms with the officers of the Michigan; and he and Thompson planned that on September 19 Cole should organize a "wine drinking" party with these officers, during which another boat was to come alongside the Michigan and attempt her capture.

The only difficulty was to find this other boat. On September 18 ,-therefore, the day before the "wine drinking," an unknown but apparently respectable man came aboard the Philo Parsons, a small steamer which ran between Detroit and Sandusky, and asked that he might stop next day at Sandwich on the Canadian shore, to pick up himself and a party of friends who wanted to go to Kelly's Island, near Sandusky. The Philo Parsons duly stopped at Sandwich, picked up this party, and further on at Malden a party of twenty more, who brought aboard a hair trunk stuffed with revolvers. She stopped again at Middle Bass 
Island, and had just started for Sandusky, when the men who had boarded her at Sandwich and Malden seized her, turned back to Middle Bass Island, and began taking in wood. The Confederates had got their boat.

At this juncture, however, a hitch occurred. The Island Queen, another lake steamer, with a cargo of passengers and soldiers, came up unsuspectingly alongside the captured Philo Parsons, and proceeded to make fast to her. Here was an encumbrance, for the Confederates neither wanted the Island Queen, nor could they let her go. So the passengers and soldiers were put ashore, and the Island Queen itself towed out into the lake and scuttled. She did not sink far, however, for the Confederates had scuttled her over a shoal, an important detail which Thompson omits in his report. Then the Philo Parsons set off for Sandusky. Here, however, the crew decided that they did not like the look of the Michigan's fourteen guns, and they turned their extempore warship around, and headed for Sandwich again. At Sandwich they put ashore a piano and some other loot, and then tried to sink the Philo Parsons. A Canadian customs house officer appeared on the scene, and took possession of the captured property (which was later returned to its owners); and it turned out that the Philo Parsons never really sank at all. After that crowded hour of glorious life she was repaired, and four days later resumed her prosaic run between Detroit and Sandusky.

As for the Michigan, the officers had never had their drinking party and would not have proved such an easy prey after all. One of Thompson's friends had given away his plans, and Cole had been arrested on September 17, with his commission from Thompson in his pocket. He, however, had had a good time in Sandusky on $\$ 4,000$ which Thompson had given him. He had been living with a lady who passed as his wife; he had apparently been more or less continuously drunk; and he was able to account for only about half the money he had received.

Meantime Toronto had been the scene of another plot, this time for the burning of New York. A Colonel Martin had reported to the Confederate chief for duty, and the latter tells us that "having nothing else on hand Colonel Martin expressed a wish to organize a corps to burn New York City." This amiable project, however, resulted in nothing more than the waste of some Greek fire and a considerable scare to the New Yorkers.

Having failed to capture the Michigan, Thompson next turned his attention to procuring a vessel useful for arming other boats 
on the lakes, and in November managed to acquire the steamer Georgiana, for which he paid $\$ 17,000$, about twice what she was worth. This news did not take long to leak out, much to Thompson's disgust. "The bane and curse of carrying out anything in this country," he wrote, "is the surveillance under which we act: Detectives or those ready to give information stand at every street corner. Two or three cannot interchange ideas without a reporter." Northern New York became convinced that the Georgiana was being armed to attack the Michigan, and was thoroughly alarmed. Troops were dispatched to garrison the lake towns, which were already disturbed by a story that one hundred Southern sympathizers were on their way to burn Buffalo. The only person who remained quite calm was the Federal Secretary of War, who wrote to General Dix, the commander of the New York troops:

War Department, November 6, 1864.

The contents of your dispatch of this date [regarding the Georgiana] have been forwarded to Mr. Seward at Auburn to be communicated to the Canadian Authorities. It is not likely that they will take any steps towards preserving the peace. You must take your own measures without reference to them. General Grant telegraphs that all the troops required have gone forward and it seems to me that you and General Butler ought to be able to take care of Jake Thompson and his gang.

(Signed) Edwin M. Stanton, Secretary of War.

As a matter of fact, the Federal authorities soon came to the conclusion that the Georgiana was not intending to match herself with the Michigan, and the tempest subsided.

In October there was another operation, for which Thompson at first got the credit, although in fact it took him as much as anybody else by surprise.

Lieutenant Bennett $\mathrm{H}$. Young, with a body of twenty-five Confederate soldiers, mostly escaped prisoners, rode over on October 19 from the Canadian line to St. Albans, and took $\$ 150,000$ in cash from three banks. Five of the citizens of the town were shot (one of them afterwards died) and the raiders dashed off in an endeavour to escape to Canada. The Provost Marshal at Burlington was ordered to pursue the marauders; and he and his 
men captured eight of them. Four or five more were captured by Canadian troops under General Williams, who had been ordered by Lord Monck to assist in their apprehension. These prisoners were taken to Montreal, and extradition proceedings were commenced, in which the Hon. Mr. Abbott was retained by the Confederate agents.

Abbott took the position that there was no case for extradition on the ground that "we conceive the strength of our position to consist in the documents we hold establishing the authority of the raiders from the C.S. Government." His defence was successful, and the captured raiders were released in December, much to the annoyance of the Federals.

The report of the agent who actually instructed Lieutenant Young is characteristic. This agent says that Young showed him letters vouching for "his integrity as a man and his piety as a Christian," and that he therefore thought him suitable for "passing through the New England States and burning some towns and robbing them of whatever he could convert to the use of the Confederate Government." Though this letter bears no signature its authorship was brought home later to Thompson's friend and colleague Clay. It was written from St. Catharines, Ontario, where Clay was then known to be living, and was identified by the Federal Department of Justice. Further evidence of Clay's activities in Montreal was supplied also by R. A. Campbell, then teller of the Ontario Bank, who disclosed during the trial of the St. Albans raiders that $\$ 50,000$ had been transferred from St. Catharines to the account of Clay and Thompson at Montreal.

The extent of the funds in the hands of these two agents was testified to by Mr. Thurston, then U.S. vice-consul at Montreal, who reported at a little later date that an informer named Sullivan had told him that their deposit in Toronto amounted to $\$ 3,000,000$. This figure is no doubt exaggerated, as Thompson himself in his report accounts for only $\$ 600,000$, of which about $\$ 100,000$ had been turned over to Clay; but even these were large sums in those days.

It may naturally be wondered how the Canadian authorities came to permit all this devising and contriving to be carried on within their borders. One reason was no doubt the fact that the total number of the Confederates in Canada available for these wild expeditions was not so large as to make their gatherings very noticeable. In November, 1863 , a Northern detective came to Canada and travelled about among the Southerners, who 
congregated chiefly in Windsor, where they patronized the Hyrons Hotel, in. Montreal, where their headquarters were at Donegana's Hotel, and in Hamilton. This man became quite convinced that the Confederate sympathizers were either unable or unwilling to make any attack on the Northern border. Such evidence is not, it is true, quite in accordance with the letter of Ogden quoted above, but it is sufficient to show that no acts were then openly committed which might endanger Canada's neutrality.

Again, a year later, Colonel Hill, who commanded the troops in Michigan, wrote to General Dix (after the attempt on the U.S.S. Michigan had failed), saying that he did not expect any raids against the Northern towns and did not believe 200 "rebels" could be obtained for such a purpose. The next month Colonel Hill changed his mind and wrote another letter in which he said he felt assured that raids would take place. But at this time the whole air was full of rumours, and the only question was the amount of credence to be given to them. On the whole, if the Federals, with their detectives operating freely in Canada, and their opportunities for obtaining information from Confederate turncoats, as happened in the case of the Philo Parsons, could not get reliable information, there is not much wonder that the Canadian authorities could do no more than they did.

The tension which existed is apparent from a letter of Secretary Stanton expressing the views of the President regarding an order of General Dix. The latter had issued instructions that if in future any raids took place the Confederates should be pursued into Canada and under no circumstances surrendered to the Canadian authorities. This was rather too strong even for the Secretary of War. He wrote to General Dix saying that the President "approves prompt and vigorous action within proper limits to protect your department and its inhabitants against hostile aggressions, and that in view of the recent action by a local British tribunal in turning loose the parties who were guilty of murder and robbery at St. Albans, every effort should be made to secure the citizens of the United States on the frontier in their persons and property against future outrages." He continues, however: "The act of invading neutral territory by military commanders is in the opinion of the President too grave and serious to be left to the discretion or will of subordinate commanders, where the facility of communication with superior authority is so speedy as it always may be with the chief authority in your department and even with the President at Washington." 
As a result, of course, General Dix's order was cancelled. General Dix pointed out that this meant that there would quite likely be no possibility of capturing raiding parties, especially when they became able to cross the river on the ice. However, the idea of attacking Ogdenburg on a winter morning does not seem to have been attractive to the Southerners, and General Dix's fears turned out to be groundless.

Thompson, during the autumn and summer, was very busy helping on the Confederate efforts to encourage the "Copperhead" peace movement in Illinois, Indiana, and Ohio, to control the Democratic convention at Chicago on August 29, and to release the Confederate prisoners at Camp Douglas. Here, again, he found convenient agents. From Canada he got in touch with the leaders of a society called the "Sons of Liberty," a secret political association, permeating all the Northern States, which had the skeleton of a military organization and adhered to the creed of "States Rights."

His first steps were to arrange for a series of peace meetings at Peoria, Springfield, and Chicago, to make which a success he agreed to supply as much money as was necessary for the purpose, and actually furnished about $\$ 75,000$. How this $\$ 75,000$ was spent no one knows; but as the second of the Peace meetings fell rather flat, it may be suspected that there was not enough money left over from the first.

During the course of the Peace meetings the Sons of Liberty were to be preparing for a general uprising on August 16, and actually began to do so, their intention being to establish armed control of Illinois, Indiana, and Ohio at a blow, then to seize Kentucky and Missouri, and so to place a tremendous weight in the balance against the northern States.

They lost their nerve, however, and some of them, declaring that the ballot box should be tried before a recourse to force, threatened to disclose the whole scheme unless the idea of a coup de main was abandoned. Naturally this ended the proceedings, much to Thompson's disappointment.

The expedition to the Chicago Convention is briefly reported by the commandant at Camp Douglas, in a letter dated November 23, 1864, to the Provost Marshal General at Washington:

About the 25th day of August last an expedition was organized at Toronto, Canada, under the immediate direction of Captain Hines, formerly of Morgans command composed of 150 to 200 
escaped prisoners and rebel soldiers, accompanied by Col. G. St. Leger Grenfell at the time Morgan's chief of Staff ${ }^{-}$This force was armed with pistols at Toronto, divided and its members in citizen's dress, came on to Chicago by different routes, on the same trains which brought the thronging thousands who assembled on the 29th of August to attend the Chicago Convention, and which made it difficult to detect their presence. It was to have been assisted by large numbers of Sons of Liberty who came armed to that Convention gathered from Kentucky, Missouri, Indiana and Illinois, and were to be under the immediate command of Brig.Gen. Charles Walsh of the Sons of Liberty.

The plan this time was first to release the 8,000 Confederate prisoners at Camp Douglas, then with about 1,500 men to capture the city itgelf, burn some of the public buildings, seize the others, gain the co-operation of the "Copperhead" element in the convention, and start a great movement which would finally swamp the Federal forces. Somehow or other these plans became known to the authorities, and strong reinforcements were sent to Camp Douglas, with the result that the expedition was a complete fiasco; nothing whatever happened, and the would-be revolutionists made the best of their way back to their homes.

Thompson, however, was quite undeterred. After the reinforcements which had been sent to the Chicago garrison in August had been released, the Federal authorities thinking that the danger was over, he organized a second expedition from Toronto. The same leaders were selected, and the attempt was fixed for November 7, the day of the presidential election. Meanwhile, the Sons of Liberty had spread about a story that armed force was to be used to prevent a Democratic victory, had made this an excuse for carrying arms themselves, had flocked into Chicago bristling with revolvers, and had organized enough mysterious meetings and deliberations to put the Federal authorities thoroughly on their guard. There were so many of them, in fact, that it was evident that they would be able to get together a force much larger than the garrison at Camp Douglas. Luck, however, was again on the side of the Federals. A man named Shanks, who had previously been in the Confederate Army, and knew Grenfell, had been for some time secretly employed as a detective

\footnotetext{
${ }^{1}$ Grenfell was an Englishman, a soldier of fortune, who had been for some time previously in the rebel service. He had more courage than brains; and he had before this been on a hunting expedition in Southern Illinois.
} 
by the commandant at Camp Douglas. He went to Grenfell's hotel stating that he was willing to assist, and Grenfell promptly gave him enough information to enable the Federal authorities to arrest all the leaders of the conspiracy. By striking at the heart of the organization, the local authorities not only defeated the plot, but found out enough about the Sons of Liberty to put an end to their activities entirely.

But the most sinister charge ever laid against the Confederate emissaries to Canada was that of sharing in the conspiracy which resulted in the assassination of Lincoln. Their speeches and actions had certainly laid them open to suspicion. Thompson had said in the summer of 1864 "that he had his friends, Confederates, all over the Northern States who were ready and willing to go any length to serve the cause of the South, that he could at any time have the tyrant Lincoln and any others of his advisors that he wanted put out of his way, and that they would not consider it a crime when done for the cause of the Confederacy." Later on, in the summer of 1864, in Montreal, Clay had a long and confidential conversation with Payne, who was afterwards tried and executed as an accomplice in the crime. Although Clay firmly denied complicity, it is difficult to believe that in this atmosphere of plot and counterplot, he had ever opposed the plan, even if he had not forwarded it, and indeed the activities in which he was known to have been engaged, his readiness to engage in schemes of violence, his disregard of the usual conventions of warfare, his continued abuse of the hospitality of Canada, are certainly evidence against him.

But it is, after all, one thing to consent to a more or less vague proposal, as this then was, and another to share in the actual plans which result in a villainous deed, and Clay and Thompson were never shown to be real accessories to the crime.

At one time it appeared as though Clay must certainly be convicted on the strength of a mass of evidence collected by a lawyer named Dunham. This man, giving the name of Sanford Conover, went to the Federal Judge Advocate General, and representing that he was in a position to find witnesses who could prove that both Jefferson Davis and Clay were accessories to the conspiracy, offered to devote his time to the work. He was provided with funds, and travelled through Canada and the South, representing that he was making good progress, and generally asking for more money. The money was provided, and Dunham, alias Conover, finally returned to Washington with a stack of affidavits 
containing evidence enough to hang Clay as high as Haman.' $\mathrm{He}$ brought some of his witnesses with him, planted them at the National Hotel at Washington, and set them to work giving depositions. They gave the most detailed and accurate descriptions of interviews and events which they claimed took place in Canada, connecting Thompson and Clay with the crime; and the only possible ground on which their stories could have been suspected was that they were too consistent.

It was not until after a report had actually been made to Congress that one of "Conovers" witnesses confessed that the whole of the evidence had been fabricated, and the depositions made out of whole cloth by "Conover" himself. Finally, it turned out that none of the witnesses had ever been in Canada or in the South, but that Conover had collected a few saloonkeepers, labourers, peddlers, and some of his own female relations, invented names and personal histories for them, supplied them with depositions which they learned by heart, and finally produced them as witnesses against Clay and Davis.

By the time all this false evidence was withdrawn, it was apparent that no charge could be made against either Clay or Thompson.

Two circumstances finally put an end to the Confederate movements in Canada. The passage of an Aliens Act by the Canadian parliament apparently prevented the conspirators from continuing their schemes during the winter months of 1864-1865; and the wave of feeling which crossed the whole country at the news of Lincoln's death made their temporary home no longer safe harbourage.

Andrew Johnson, Lincoln's successor, promptly issued a proclamation charging Thompson and Clay with complicity in the assassination plot, offering a reward for the apprehension of either of them, and after this they thought that the quicker they shook the dust of Canada off their feet the better. Clay left for Macon, where he gave himself up; Thompson departed for Portland, Maine; and the work of the Confederate "Hidden Hand" was over.

The two men had plotted a great deal, spent an enormous amount of money, caused the death of a number of innocent people and of some of their own misguided subordinates, and accomplished absolutely nothing. Sometimes they had chosen their assistants badly; once or twice luck had been against them; but the greatest of their errors was that they entirely misjudged 
the spirit of the people they were fighting. The only result of the greatest of their efforts, the attempt to capture Chicago and seize Illinois and Indiana, was to make possible the destruction of the very machinery on which they relied.

It is a relief to turn from the record of these plottings and plannings to the story of the forty-eight thousand Canadians who fought among the Northern armies, not for the sake of loyalty or allegiance, not in answer to an appeal or under the pressure of conscription, but because they believed their cause was just; and to the memory of the eighteen thousand of them who gave up their lives for the freedom of others.

WILFRID BoveY 